\title{
ПРОГНОЗИРОВАНИЕ ГЛУБИНЫ НАЧАЛА ОБРАЗОВАНИЯ АСФАЛЬТЕНОСМОЛОПАРАФИНОВЫХ ОТЛОЖЕНИЙ В НЕФТЕДОБЫВАЮЩИХ СКВАЖИНАХ
}

\author{
Поплыгин Владимир Валерьевич1, \\ poplygin@bk.ru
}

Немтина Светлана Александровна², nemtinasvetlana@yandex.ru

\author{
1 Пермский национальный исследовательский политехнический университет, \\ Россия, 616990, г. Пермь, Комсомольский пр., 29. \\ 2 ООО «ПИТЦ "Геофизика"», \\ Россия, 618706, г. Добрянка, рп. Полазна, Электронный проезд, 3.
}

\begin{abstract}
Актуальность. В настоящее время добыча нефти на ряде месторождений осложнена образованием асфальтеносмолопарафриновых отложений на поверхности нефтепромыслового оборудования. Образование отложений приводит к уменьшению полезного сечения насосно-компрессорных труб и повышенному износу насосного оборудования, уменьшению добьчи нефрти. Цель: исследовать аналитические модели определения глубины начала образования отложений асфральтенов, смол и парафинов в скважинах; оценить влияние технологических параметров добычи (обводненность, дебит, давление и др.) на глубину начала образования отложений асфральтенов, смол и парафинов.

Объект: Шершневское месторождение Пермского края.

Методы: лабораторные исследования, анализ промысловых данных, компьютерное моделирование.

Результаты. Выполнен обзор состава и свойств пластовых фрлюидов Шершневского месторождения. Проведено обобщение моделей для прогнозирования глубины начала интенсивного образования асфральтенов, смол и парафинов на стенках глубиннонасосного оборудования. Выявлено, что для прогнозирования образования ассральтеносмолопарафиновых отложений, а также для подбора наиболее оптимальной технологии борьбы с ними необходимо учитывать, помимо температуры потока, обводненность продукции, противодавление на устье, скорость потока. Определение глубины начала интенсивной парафичнизации скважинной продукции на примере добывающих скважин Шершневского нефртяного месторождения показало, что наблюдается тенденция к снижению глубины начала формирования асфральтеносмолопарафиновых отложений с ростом обводненности и дебита скважины по жидкости. С увеличением обводненности продукции скважин глубина начала образования асфральтеносмолопарафриновых отложений уменьшается в среднем на 20 м при росте обводненности на 10 \%. С увеличением на 1 МПа буфрерного давления глубина начала образования асфальтеносмолопарафриновых отложений увеличивается на 30 м. При росте частоты тока электродвигателя на 2 Ги глубина начала парафинизации скважинной увеличивается на 28 м.
\end{abstract}

\section{Ключевые слова:}

Скважина, парафин, обводненность, температура, глубина, давление.

\section{Введение}

Одной из серьезных проблем при эксплуатации нефтедобывающих скважин является возникновение асфальтосмолопарафиновых отложений (АСПО) в призабойных зонах, на глубиннонасосном оборудовании и др. В специальной литературе широко освещено влияние различных факторов на интенсивность и глубину начала выпадения АСПО в добывающих скважинах, причины и механизм их выпадения [1-7]. Основными факторами, влияющими на глубину и интенсивность начала образования АСПО, являются: давление, температура, скорость потока, состав флюидов. В [8-13] рассмотрены механизмы и предложены методы оценки интенсивности проявления АСПО, исходя из геологофизических и технологических параметров.

В настоящей статье для добывающих скважин Шершневского нефтяного месторождения выполнена оценка глубины начала образования АСПО от основных технологических параметров эксплуатации.

Нефть объектов разработки Шершневского месторождения характеризуется как средняя по плотности, маловязкая $(2,94-4,04 \quad$ мПа·c), высокосмолистая (15,01-15,99 мас. \% смол и 1,64-3 мас. \% асфальте- нов), парафинистая (4,97-5,47 мас. \%), сернистая $(1,67-1,76$ мас. \%).

Все скважины оборудованы установками электроцентробежных насосов.

Температура насыщения парафином дегазированной нефти, как правило, определяется в лабораторных условиях. В случае отсутствия лабораторных данных температура насыщения парафином дегазированной нефти может быть рассчитана по эмпирическим зависимостям из [15-20]. В [14] определены корреляционные коэффициенты для нефти Шершневского месторождения для оценки температуры насыщения парафином. Наилучшая сходимость расчетных параметров с фактическими по добывающим скважинам месторождений севера Пермского края получена по зависимости из [21].

В таблице приведены значения температуры насыщения парафином дегазированной нефти для терригенных (Тл, Бб, Мл) и карбонатных объектов (Т-Фм) разработки Шершнёвского месторождения. Температура насыщения нефти парафином определена по формуле:

$$
t_{\text {нд }}=t_{\text {пл пар }} e^{-X\left(C_{\Pi} ; C_{\mathrm{C}} ; C_{\mathrm{A}} ; \frac{\mu_{20}}{\mu_{50}}\right)},
$$


где $t_{\text {пл.пар }}$ - температура плавления парафина; $C_{П}, C_{\mathrm{C}}$ $C_{\mathrm{A}}-$ содержание в нефти парафинов, смол и асфальтенов; $\frac{\mu_{20}}{\mu_{50}}-$ отношения динамических вязкостей нефти при температурах 20 и $50{ }^{\circ} \mathrm{C} ; X$ - показатель степени.

Изменение $t_{\text {нд }}$ по глубине скважины № 230 Шершнёвского месторождения приведено на рис. 1.
Для определения глубины начала интенсивного отложения парафинов на глубиннонасосном оборудовании сопоставлены кривые распределения температуры потока жидкости в скважине и температуры насыщения нефти парафином (рис. 1). Место пересечения кривых является глубиной начала образования АСПО в скважине. Расчетная глубина начала интенсивной парафинизации продукции 1260 м.

Таблица. Результаты расчета температуры насыщения парафином дегазированной нефти Шершнёвского месторождения

Table. $\quad$ Results of calculating the wax saturation temperature of degassed oil from the Shershnevskoe field

\begin{tabular}{|c|c|c|c|c|c|c|c|}
\hline \multirow{2}{*}{$\begin{array}{c}\text { Объект разработки } \\
\text { Reservoir }\end{array}$} & \multirow{2}{*}{$\mu_{20} / \mu_{50}$} & \multicolumn{3}{|c|}{$\begin{array}{c}\text { Содержание в нефти, мас. \% } \\
\text { Content in oil, \% wt. }\end{array}$} & \multirow{2}{*}{$\begin{array}{l}t_{\text {пл пар }},{ }^{\circ} \mathrm{C} \\
t_{\text {pl par }},{ }^{\circ} \mathrm{C}\end{array}$} & \multirow{2}{*}{$\begin{array}{c}\text { Показатель } \\
\text { степени X } \\
\text { X }\end{array}$} & \multirow{2}{*}{$t_{\mathrm{Hд}} / t_{n d},{ }^{\circ} \mathrm{C}$} \\
\hline & & $C_{\Pi}$ & $C_{\mathrm{C}}$ & $\bar{C} C_{\mathrm{A}}$ & & & \\
\hline Тл/Т1 & 3,99 & 5,08 & 14,01 & 1,85 & 56,1 & 0,61 & 30,48 \\
\hline Мл/M1 & 3,52 & 5,15 & 15,99 & 2,11 & 54,9 & 0,62 & 29,53 \\
\hline Бб/Вb & 3,61 & 5,47 & 13,89 & 1,64 & 55 & 0,64 & 29,00 \\
\hline $\mathrm{T}-\Phi_{\mathrm{M}} / \mathrm{T}-\mathrm{Fm}$ & 3,90 & 4,97 & 14,35 & 3,00 & 55 & 0,62 & 29,59 \\
\hline
\end{tabular}

Температура, ${ }^{\circ} \mathrm{C}$

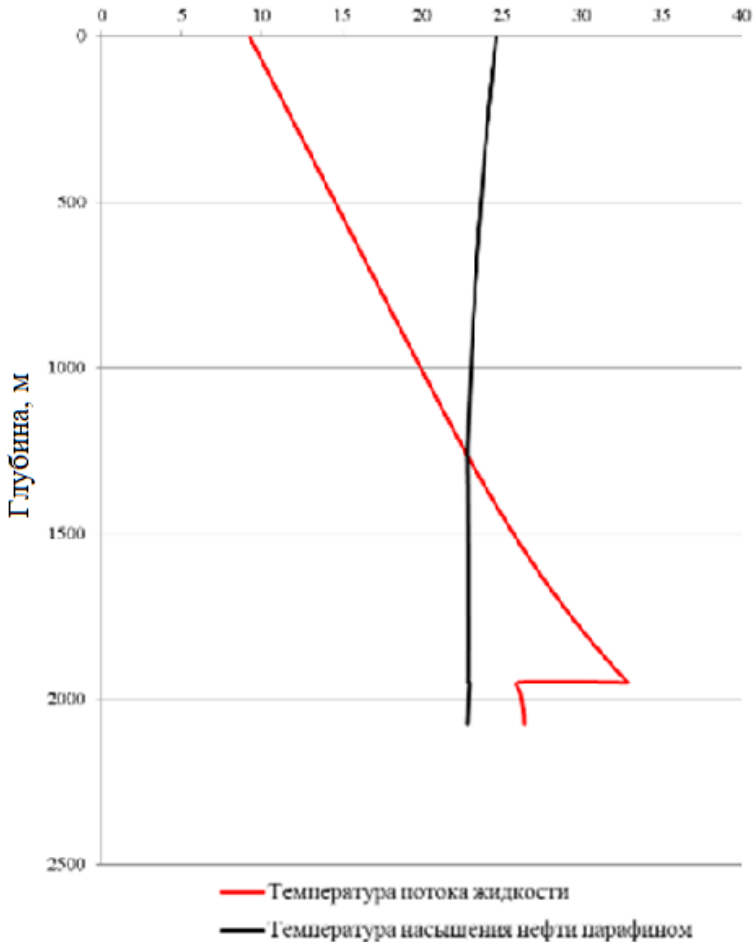

Pис. 1. Графическая оценка глубины начала отложений асфальтенов, смол и парафинов в скважине

Fig. 1. Graphical assessment of the depth of asphaltenes, resins and paraffins deposition start in the well

Выполнено определение глубин начала интенсивной парафинизации продукции 28 скважин, работающих в суточном режиме откачки. Глубина начала образования АСПО изменяется от 975 до 1770 м (рис. 2). Отмечено снижение глубины начала интенсивной парафинизации с увеличением дебита в среднем на 8 м при увеличении дебита жидкости на $1 \mathrm{~m}^{3} /$ сут.

При подземном ремонте по ряду скважин выполнены замеры толщины АСПО на внутренней поверхности НКТ. Произведен анализ соответствия расчетной и фактической глубин начала отложений асфальтенов, смол и парафинов в скважине (рис. 3). Отмеча- ется сходимость расчетных и фактических параметров с максимальным отклонением в 8,14 \%.

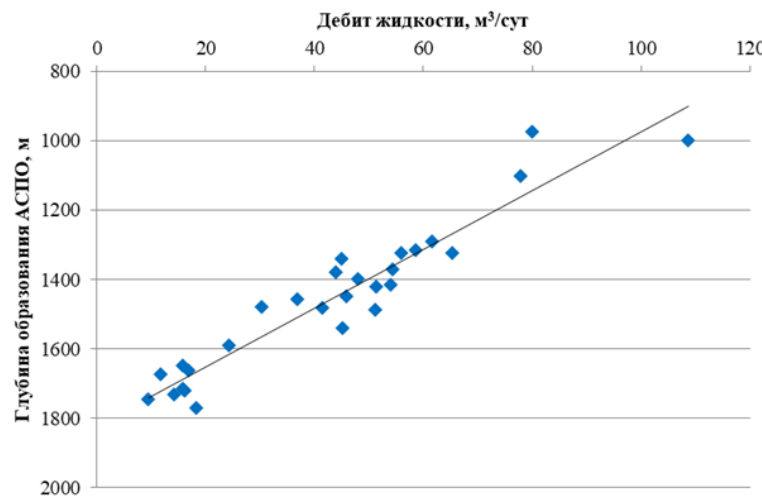

Рис 2. Зависимость глубины выпадения АСПО от дебита по жидкости

Fig. 2. Dependence of wax deposition depth on liquid flow rate

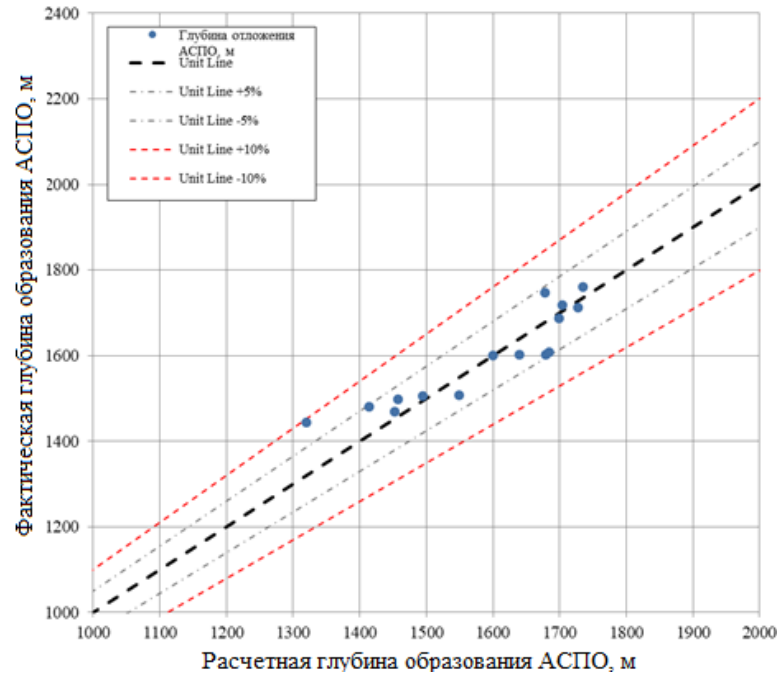

Рис. 3. Сопоставление расчетных и фактических глубин образования АСПО

Fig. 3. Comparison of calculated and actual depths of wax formation 
B программном продукте Petroleum Experts PROSPER произведена оценка влияния обводненности продукции скважин на глубину выпадения АСПО С увеличением обводненности продукции скважин глубина начала образования АСПО уменьшается в среднем на 20 м при росте обводненности на $10 \%$.

С увеличением на 1 МПа буферного давления глубина начала образования АСПО увеличивается на 30 м.

Важным параметром, влияющим на образование АСПО на поверхности нефтепромыслового оборудования, является скорость потока жидкости в колонне насосно-компрессорных труб. С увеличением скорости потока жидкости происходит уменьшение градиента температуры по стволу скважины, уменьшается скорость накопления АСПО. Для анализа влияния скорости потока на глубину образования АСПО проведен расчет при различных частотах работы насоса. Установлено, что с увеличением частоты тока элек-

\section{СПИСОК ЛИТЕРАТУРЫ}

1. Wax deposition mechanisms: Is the current description sufficient? / J. Yang, Y. Lu, N. Daraboina, C. Sarica // Fuel. - 2020. - V. 275. Article number 117937.

2. Aguia J.I.S., Punase A., Mazzeo C. Influence of asphaltene inhibitors on wax and asphaltene deposition - Are problems associated? // Offshore Technology Conference Brasil 2019. - OTCB 2019. Code 157170.

3. Research progress and discussion of waxy crude pour point depressants: A mini review / Z. Sun, J. Zhang, G. Jing, Y. Liu, S. Liu // Recent Innovations in Chemical Engineering. - 2020. - V. 13. № 4. - P. 323-331.

4. Sousa A.L., Matos H.A., Guerreiro L.P. Preventing and removing wax deposition inside vertical wells: a review // Journal of Petroleum Exploration and Production Technology. - 2019. - V. 9. № 3. - P. 2091-2107.

5. Prediction of wax disappearance temperature by intelligent models X.-Q. Bian, J.-H. Huang, Y. Wang, Y.-B. Liu, D.T. Kaushika Kasthuriarachchi, L.-J. Huang // Energy and Fuels. - 2019. - V. 33. № 4. - P. 2934-2949.

6. Akinyemi O.P., Udonne J.D., Oyedeko K.F. Study of effects of blend of plant seed oils on wax deposition tendencies of Nigerian waxy crude oil // Journal of Petroleum Science and Engineering. 2018. - V. 161. - P. 551-558.

7. Ашмян К.Д., Никитина И.Н, Носова Е.Н. Факторы, влияющие на выпадение из нефти асфальтосмолопарафиновых веществ // Нефтяное хозяйство. - 2014. - № 11. - С. 126-128.

8. Sandyga M.S., Struchkov I.A., Rogachev M.K. Formation damage induced by wax deposition: laboratory investigations and modeling // Journal of Petroleum Exploration and Production Technology. - 2020. - V. 10. - № 6. - P. 2541-2558.

9. Magnini M., Matar O.K. Fundamental study of wax deposition in crude oil flows in a pipeline via interface-resolved numerical simulations // Industrial and Engineering Chemistry Research. 2019. - V. 58. - № 47. - P. 21797-21816.

10. Study on wax deposition mechanism and kinetics of wellbore in Longdong area / J.-J. Jing, W.-Y. Fu, C. Peng, J.-G. Zheng, M.-L. Niu, D. Li, W.-H. Li // Huaxue Gongcheng/Chemical Engineering. -2019 . - V. 47. - № 11. - P. 68-73.

11. Revisiting the methodology for asphaltenes precipitation D. Santos, M. Amaral, E.B.M. Filho, R.S. Dourado, J.A.P. Coutinho, тродвигателя на 2 Гц глубина начала парафинизации скважинной увеличивается на 28 м.

\section{Заключение}

Для прогнозирования глубины образования, а также подбора наиболее оптимальной технологии борьбы с АСПО необходимо учитывать температуру потока, обводненность продукции, противодавление на устье, скорость потока.

Определение глубины начала интенсивной парафинизации скважинной продукции на примере добывающих скважин Шершневского нефтяного месторождения показало, что наблюдается тенденция уменьшения глубины начала отложений асфальтенов, смол и парафинов в скважине с ростом обводненности и дебита скважины по жидкости. С увеличением противодавления на устье скважины глубина начала образования АСПО увеличивается.

G.R. Borges, E. Franceschi, C. Dariva // Journal of Petroleum Science and Engineering. - 2019. - V. 178. - P. 778-786

12. Struchkov I.A., Rogachev M.K. The challenges of waxy oil production in a Russian oil field and laboratory investigations // Journal of Petroleum Science and Engineering. - 2018. - V. 163. - P. 91-99.

13. Рогачев М.К., Стрижнев К.В Борьба с отложениями при добыче нефти. - М.: ООО «Недра-Бизнесцентр», 2006. - 295 с.

14. Турбаков М.С. Обоснование и выбор технологий предупреждения и удаления асфальтеносмолопарафиновых отложений в скважинах: автореф. дис. ... канд. техн. наук. - СПб., 2011. $20 \mathrm{c}$.

15. Справочное руководство по проектированию разработки и эксплуатации нефтяных месторождений. Добыча нефти / Р.С. Андриасов, И.Т. Мищенко, А.И. Петров, В.Н. Васильевский / под общ. ред. Ш.К. Гиматудинова. - М.: Альянс, 2007. - 454 с.

16. Мищенко И.Т. Скважинная добыча нефти. - М.: Изд-во «Нефть и газ» РГУ нефти и газа им. И.М. Губкина, 2003. $816 \mathrm{c}$.

17. Коробов Г.Ю., Мордвинов В.А. Распределение температуры по стволу добывающей скважины // Нефтяное хозяйство. 2013. - № 4. - С. 57-59.

18. Мордвинов В.А., Турбаков М.С., Ерофеев А.А. Методика оценки глубины начала интенсивной парафинизации скважинного оборудования // Нефтяное хозяйство. - 2010. - № 7. C. $112-115$

19. Определение глубины начала кристаллизации парафина / А.В. Осипов, А.А. Галиуллин, М.А. Пискарев, О.А. Грибенников // Научные исследования: от теории к практике. 2016. - № 3. - C. 205-208.

20. Смаилова Г.Ж. Изучение динамики отложения твердого парафина в НКТ глубинно-насосных скважин при добыче высокопарафинистой нефти // Нефтегазовые технологии и новые материалы. Проблемы и решения. Сборник научных трудов. Уфа, 2016. - С. 158-164.

21. Турбаков М.С., Ерофеев А.А., Лекомцев А.В. К определению глубины начала образования асфальтеносмолопарафиновых отложений при эксплуатации нефтедобывающих скважин // Геология, геофизика и разработка нефтяных и газовых месторождений. - 2009. - № 10. - С. 62-65.

Поступила 10.03.2021 г.

\section{Информация об авторах}

Поплыгин В.В., кандидат технических наук, доцент кафедры нефтегазовых технологий, Пермский национальный исследовательский политехнический университет.

Немтина С.А., специалист, ООО «ПИТЦ "Геофизика"». 


\title{
PREDICTION OF THE DEPTH OF WAX DEPOSITION START IN OIL WELLS
}

\author{
Vladimir V. Poplygin 1 , \\ poplygin@bk.ru
}

\author{
Svetlana A. Nemtina², \\ nemtinasvetlana@yandex.ru \\ 1 Perm National Research Polytechnic University, \\ 29, Komsomolsky avenue, Perm, 614990, Russia. \\ 2 PITC Geofizika LLC, \\ 3, Elektronny proezd, Polazna, Dobryanka, 618706, Russia.
}

Relevance. At present, oil production in a number of fields is complicated by the formation of asphaltene-resin-paraffin deposits on the surface of oil field equipment. The formation of deposits leads to decrease in tubing useful section and increased wear of pumping equipment, decrease in oil production.

The aim of the research is to investigate the analytical models for determining the depth of the onset of asphaltene, tar and paraffin deposits in wells; assess the influence of production technological parameters (water cut, flow rate, pressure, etc.) on the depth of the beginning of formation of asphaltenes, resins and paraffins deposits.

Object: Shershnevskoe field of the Perm region.

Methods: laboratory research, field data analysis, computer modeling.

Results. The authors have reviewed the composition and properties of formation fluids of the Shershnevskoe field. The generalization of the models is carried out to predict the depth of the beginning of the intensive formation of asphaltenes, resins and paraffins on the walls of downhole pumping equipment. It was revealed that in order to predict the formation of asphaltene-resin-paraffin deposits, as well as the selection of the most optimal technology to combat them, it is necessary to take into account, in addition to the flow temperature, the water cut of the product, the back pressure at the wellhead, and the flow rate. Determination of the depth of the beginning of intensive waxing of well products using the example of production wells of the Shershnevskoe oil field showed that there is a tendency to decrease the depth of the beginning of the formation of asphaltene-resin-paraffin deposits with increase in water cut and well flow rate by liquid. With increase in the water cut of well production, the depth of the onset of asphaltene-resin-paraffin deposits formation decreases on average by $20 \mathrm{~m}$ with growth in water cut by $10 \%$. With increase in the buffer pressure by $1 \mathrm{MPa}$, the depth of the beginning of formation of asphalteneresin-paraffin deposits increases by $30 \mathrm{~m}$. With increase in the frequency of the electric motor current by $2 \mathrm{~Hz}$, the depth of the beginning of borehole waxing grows by $28 \mathrm{~m}$.

\section{Key words:}

Well, paraffin, water cut, temperature, depth, pressure.

\section{REFERENCES}

1. Yang J., Lu Y., Daraboina N., Sarica C. Wax deposition mechanisms: Is the current description sufficient? Fuel, 2020, vol. 275, Article number 117937.

2. Aguia J.I.S., Punase A., Mazzeo C. Influence of asphaltene inhibitors on wax and asphaltene deposition - Are problems associated? Offshore Technology Conference Brasil 2019. OTCB 2019, Code 157170.

3. Sun Z., Zhang J., Jing G., Liu Y., Liu S. Research progress and discussion of waxy crude pour point depressants: A mini review. Recent Innovations in Chemical Engineering, 2020, vol. 13, no. 4, pp. 323-331.

4. Sousa A.L., Matos H.A., Guerreiro L.P. Preventing and removing wax deposition inside vertical wells: a review. Journal of Petroleum Exploration and Production Technology, 2019, vol. 9, no. 3, pp. 2091-2107.

5. Bian X.-Q., Huang J.-H., Wang Y., Liu Y.-B., Kaushika Kasthuriarachchi D.T., Huang L.-J. Prediction of wax disappearance temperature by intelligent models. Energy and Fuels, 2019, vol. 33, no. 4, pp. 2934-2949.

6. Akinyemi O.P., Udonne J.D., Oyedeko K.F. Study of effects of blend of plant seed oils on wax deposition tendencies of Nigerian waxy crude oil. Journal of Petroleum Science and Engineering, 2018, vol. 161, pp. 551-558.

7. Ashmyan K.D., Nikitina I.N., Nosova E.N. Factors influencing the loss of oil asphaltene, resin and paraffin substances. Oil Industry, 2014, vol. 11, pp. 126-128. In Rus.

8. Sandyga M.S., Struchkov I.A., Rogachev M.K. Formation damage induced by wax deposition: laboratory investigations and model- ing. Journal of Petroleum Exploration and Production Technology, 2020, vol. 10, no. 6, pp. 2541-2558.

9. Magnini M., Matar O.K. Fundamental study of wax deposition in crude oil flows in a pipeline via interface-resolved numerical simulations. Industrial and Engineering Chemistry Research, 2019, vol. 58, no. 47, pp. 21797-21816.

10. Jing J.-J., Fu W.-Y., Peng C., Zheng J.-G., Niu M.-L., Li D., Li W.-H. Study on wax deposition mechanism and kinetics of wellbore in Longdong area. Huaxue Gongcheng/Chemical Engineering, 1 November 2019, vol. 47, Iss. 11, pp. 68-73.

11. Santos D., Amaral M., Filho E.B.M., Dourado R.S., Coutinho J.A.P., Borges G.R., Franceschi E., Dariva C. Revisiting the methodology for asphaltenes precipitation. Journal of Petroleum Science and Engineering, 2019, vol. 178, pp. 778-786.

12. Struchkov I.A., Rogachev M.K. The challenges of waxy oil production in a Russian oil field and laboratory investigations. Journal of Petroleum Science and Engineering, 2018, vol. 163, pp. 91-99.

13. Rogachev M.K., Strizhnev K.V. Borba s otlozheniyami pri dobyche nefti [Oil recovery sediment control]. Moscow, OOO «NedraBiznestsentr» Publ., 2006. 295 p.

14. Turbakov M.S. Obosnovanie $i$ vybor tekhnologiy preduprezhdeniya $i$ udaleniya asfaltenosmoloparafinovykh otlozheniy $v$ skvazhinakh. Avtoreferat Dis. Kand. nauk [Justification and selection of technologies for prevention and removal of asphaltene-resinparaffin deposits in wells. Cand. Diss. Abstract]. St-Petersburg, 2011. $20 \mathrm{p}$.

15. Andriasov R.S., Mishchenko I.T., Petrov A.I., Vasilevskii V.N. Spravochnoe rukovodstvo po proektirovaniyu razrabotki i ekspluatatsii neftyanykh mestorozhdeniy. Dobycha nefti [Reference guide for the design, development and operation of oil fields. Oil produc- 
tion]. Ed. by Sh.K. Gimatudinov. Moscow, Alianse Publ., 2007. $454 \mathrm{p}$.

16. Mishchenko I.T. Skvazhinnaya dobycha nefti [Well oil production]. Moscow, «Neft i gaz» RGU nefti i gaza im. I.M. Gubkina Publ., $2003.816 \mathrm{p}$.

17. Korobov G.Yu., Mordvinov V.A. Temperature distribution along well bore. Oil Industry, 2013, vol. 4, pp. 57-59. In Rus.

18. Mordvinov V.A., Turbakov M.S., Erofeev A.A. The estimation technique of depth of intensive formation of paraffin sediments on downhole equipment. Oil Industry, 2010, vol. 7, pp. 112-115. In Rus.

19. Osipov A.V., Galiullin A.A., Piskarev M.A., Gribennikov O.A. Opredelenie glubiny nachala kristallizatsii parafina [Determination of the depth of the beginning of crystallization of wax]. Nauchnye issledovaniya: ot teorii k praktike, 2016, vol. 3, pp. 205-208.
20. Smailova G.Zh. Izuchenie dinamiki otlozheniya tverdogo parafina v NKT glubinno-nasosnykh skvazhin pri dobyche vysokoparafinistoy nefti [The study of the dynamics of the deposition of solid wax in the tubing of deep-well pumping wells during the production of highly paraffinic oil]. Neftegazovye tekhnologii i novye materialy. Problemy i resheniya. Sbornik nauchnykh trudov [Oil and gas techniques and new materials. Problems and solutions. Proc.]. Ufa, 2016. pp. 158-164.

21. Turbakov M.S., Erofeev A.A., Lekomtsev A.V. Depth definition of the beginning of asphaltene-resin-paraffin deposits formation during operation of oil producing wells. Geologiya, geofizika $i$ razrabotka neftyanykh i gazovykh mestorozhdeniy, 2009, vol. 10, pp. 62-65. In Rus.

Received: 10 March 2021.

\section{Information about the authors}

Vladimir V. Poplygin, Cand. Sc., associate professor, Perm National Research Polytechnic University.

Svetlana A. Nemtina, specialist, PITC Geofizika LLC. 